\title{
Heavy metals in sediments of water bodies in the Służew stream catchment (Warsaw area)
}

\author{
Metale ciężkie w osadach zbiorników wodnych \\ w zlewni Potoku Służewieckiego (Warszawa)
}

* Prof. dr hab. Izabela Bojakowska, mgr inż. Dariusz Lech, Polish Geological Institute - National Research Institute, Rakowiecka 4 St., 00-975 Warsaw, Poland, phone: +48 224592 296, e-mail: izabela.bojakowska@pgi.gov.pl, dariusz.lech@pgi.gov.pl

Keywords: heavy metals, freshwater sediments, water bodies, catchment, Służew Stream (Potok Służewiecki) Słowa kluczowe: metale ciężkie, osady wodne, zbiorniki wodne, zlewnia, Potok Służewiecki

\section{Abstract}

The Służew Stream, a $14.9 \mathrm{~km}$ long watercourse, is part of an ancient river called Sadurka that starts its course in the Warsaw district of Ochota and flows into the Wilanów Lake. In the $19^{\text {th }}$ and $20^{\text {th }}$ centuries, the watercourse received industrial and municipal sewage from Warsaw and its environs, but nowadays only rain and snow meltwater is discharged into the stream. Freshwater sediments of five reservoirs in the catchment area of the Służew Stream - Wilanów Lake, Powsinów Lake, Pond in the Horse Racing area, Lake at Morgi and South Pond in the Wilanów Park were analysed for the contents of $\mathrm{Cr}, \mathrm{Cu}, \mathrm{Pb}, \mathrm{Zn}, \mathrm{Ni}, \mathrm{Cd}$ and $\mathrm{Hg}$ The following concentrations have been determined: chromium from 5 to $274 \mathrm{mg} / \mathrm{kg}$, copper - from 5 to $274 \mathrm{mg} / \mathrm{kg}$, lead - from 3 to $310 \mathrm{mg} / \mathrm{kg}$, zinc - from 44 to $1430 \mathrm{mg} / \mathrm{kg}$, nickel - from 3 to $55 \mathrm{mg} / \mathrm{kg}$, cadmium - from 0.3 to $37.3 \mathrm{mg} / \mathrm{kg}$ and mercury - from 0.010 to $0.810 \mathrm{mg} / \mathrm{kg}$ (Fig. 2-5). The studies have shown that water sediments of Pond in the Horse Racing area, South Pond and Wilanów Lake, supplied by the Służew Stream waters, are characterised by a very high content of heavy metals. In contrast, water sediments of Powsinów Lake and Lake at Morgi, recharged by drainage ditches flowing into the stream, are characterised by much lower concentrations of these elements, but the levels are still much greater than the geochemical background

(C) IOŚ-PIB

\section{INTRODUCTION}

Contamination of watercourses and other water bodies with heavy metals in urban areas is a common phenomenon (Landre et al. 2011; Sekabira et al. 2010; Jumbe, Nandini 2009). For many years urban and industrial effluents were the main source of pollution. Currently, in post-industrial urban areas, heavy metals are brought into surface water mainly by rain runoff and meltwater from melting snow piles (Adachi, Tainosho 2004; Lindström 2001). Rain runoff and meltwater carry many pollutants such as air dust and petroleum products, crumbs of tires, asphalt, exfoliated paints, varnish and rust, anti-ice chemicals, as well as fertilizers and herbicides applied on lawns and in parks. Street dust contains up to several
** Mgr Jadwiga Jaroszyńska, Chemical Laboratory, MPO, Kampinoska 1 St. 01-934 Warsaw, Poland, e-mail: jadwiga.jaroszynska@mpo.com.pl

\section{Streszczenie}

Potok Służewiecki, ciek o długości 14,9km jest fragmentem dawnej rzeki Sadurki; rozpoczyna on swój bieg w dzielnicy Warszawa-Ochota a ujście jego stanowi Jezioro Wilanowskie. W XIX i XX wieku ciek przyjmował ścieki przemysłowe i komunalne z Warszawy i jej okolic, obecnie do Potoku odprowadzane sa jedynie ścieki opadowe i spływy roztopowe. W osadach pięciu zbiorników wodnych znajdujących się w zlewni Potoku Służewieckiego: Jeziora Wilanowskiego, Jeziora Powsinkowskiego, Stawu Wyścigi, Jeziora pod Morgami oraz Stawu Południowego w Parku Wilanowskim (rysunek 1) określono zawartość $\mathrm{Cr}, \mathrm{Cu}, \mathrm{Pb}, \mathrm{Zn}, \mathrm{Ni}, \mathrm{Cd}$ i Hg. W zbadanych osadach zawartość chromu była w zakresie od 5 do $274 \mathrm{mg} / \mathrm{kg}$, miedzi - od 5 do $274 \mathrm{mg} / \mathrm{kg}$, ołowiu - od 3 do $310 \mathrm{mg} / \mathrm{kg}$, cynku - od 44 do $1430 \mathrm{mg} / \mathrm{kg}$, niklu - od 3 do $55 \mathrm{mg} / \mathrm{kg}$, kadmu - od 0,3 do 37,3 mg/kg, a rtęci - od 0,010 do 0,810 mg/kg (rysunki 2-5). Badania wykazały, że osady zbiorników zasilanych wodami Potoku Służewieckiego - Staw Wyścigi, Staw Południowy i Jezioro Wilanowskie charakteryzują się bardzo wysokimi zawartościami metali ciężkich. Podczas gdy osady Jeziora Powsinkowskiego i Jeziora pod Morgami, zasilanych wodami rowów melioracyjnych uchodzących do Potoku, charakteryzuja się dużo niższymi stężeniami badanych pierwiastków, lecz są one znacznie wyższe od wartości ich tła geochemicznego. $\mathrm{mg} / \mathrm{kg}$ of cadmium, up to several hundred $\mathrm{mg} / \mathrm{kg}$ of copper, chromium, nickel and lead, and sometimes $>1000 \mathrm{mg} / \mathrm{kg}$ of zinc (Zhao et al. 2009; Bojakowska et al. 2009; Christofordis, Stamatis 2009; Okoro et al. 2007; Shinggu et al. 2007; Ferreira-Baptista, Migiel 2005; Ordóñez et al. 2003; Sezgin et al. 2003). Currently, the most common metals in street dust, associated with road transport, are copper, zinc, cadmium, chromium, nickel and iron from corrosion of cars, tire wear and brake discs, and in recent years platinum, palladium and rhodium also (McKenzie et al. 2009; Guney et al. 2009; Legret, Pagotto 2006). For tens of years, the key metal of street dust was lead originating from the combustion of 
leaded petrol (Okoro et al. 2007; Nageotte, Day 1998). Important elements in street dust are also mercury and arsenic originating from the burning of coal (Kabata-Pendias, Mukherjee 2007). The source of zinc, copper, lead and cadmium is corrosion of roofs on buildings (galvanized metal, tar board, copper plate) and building facades affected by weathering (Polkowska, Namieśnik 2008; Baker 2009; Lindström 2001; Quek, Forster 1993).

Pollution of modern water sediments is one of the most important environmental problems, as most of potentially harmful metals, running into the environment, are accumulated in water sediments. The presence of high levels of potentially harmful constituents in sediments (such as zinc, copper, chromium, cadmium, lead, nickel, mercury as well as polycyclic aromatic hydrocarbons and organochlorine pesticides) has a negative impact on the quality of surface waters. Bottom-sediment contaminants may accumulate in the trophic chain to a level that is toxic to aquatic organisms, especially predators, and may pose a risk to humans and wild animals consuming fish or shellfish inhabiting the places where such polluted deposits occur (Vink 2009).

\section{SCOPE AND RESEARCH METHODS}

The Służew Stream (Potok Służewiecki) is a $14.9 \mathrm{~km}$ long watercourse being part of an ancient river of Sadurka that started running between the current Warsaw West railway station and the village of Włochy, and flowed into Czerniaków Lake (Jeziorko Czerniakowskie). The original flow of the Sadurka River was changed at the end of the $17^{\text {th }}$ century, when it was directed to Wilanów to improve the poorly functioning water system in the royal residence (Biernacki 2000). Currently, the Służew Stream begins in the Warsaw district of Ochota at Aleja Krakowska Str., and flows into Wilanów Lake (Jezioro Wilanowskie). The waters of Wilanów Lake flow through the Sobieski Canal (Kanał Sobieskiego) to the Wilanówka River, a left tributary of the Vistula River. In the $19^{\text {th }}$ to early $20^{\text {th }}$ century, the watercourse became a canal path collecting industrial and municipal wastewater, rainwater runoff, snowmelt and discharges of the stormwater drainage system. Currently, the discharge of wastewater from the industrial sewage system into the stream has been virtually eliminated and only rainwater and snowmelt runoff are discharged into the watercourse. There are numerous bodies of water within the Służew Stream catchment area, including Wilanów Lake, South Pond (Staw Południowy) in the Wilanów Park, Powsinów Lake (Jezioro Powsinkowskie), Lake at Morgi (Jezioro Pod Morgami) and a Pond in the Horse Racing area (Staw Wyścigi Konne).

Studies of water sediments in the Służew Stream catchment were conducted during 2007-2010. The study included the following water bodies:

- Wilanów Lake with an area of 15 hectares, which is part of the ancient string of left-bank oxbow lakes of the Vistula River, fed by waters of the Służew Stream,

- Powsinów Lake connected with Wilanów Lake, recharged by waters of the ditches: Powsinów Ditch and Natolin Ditch,

- Pond in the Horse Racing area with the capacity of $28,000 \mathrm{~m}^{3}$, which is a flow-through lake dammed on the Służew Stream,

- Lake at Morgi with the area of 2.5 ha, formed as a result of damming of irrigation canals located in Wilanów, as well as of Powsinów Ditch (eastern link) and Natolin Ditch (western link), and

- South Pond in the Wilanów Park, recharged by waters of the Służew Stream.

Four sampling points were located in Wilanów Lake, two observation points in Powsinów Lake, while the samples were collected from single observation points from Pond in the Horse Racing area, South Pond in the Wilanów Park, and Lake at Morgi (Fig. 1) Powsinów Lake, Wilanów Lake and Lake at Morgi were sampled 16 times, while the ponds of South Pond and Pond in the Horse Racing area were sampled 10 times during 2007-2010. A Kajak

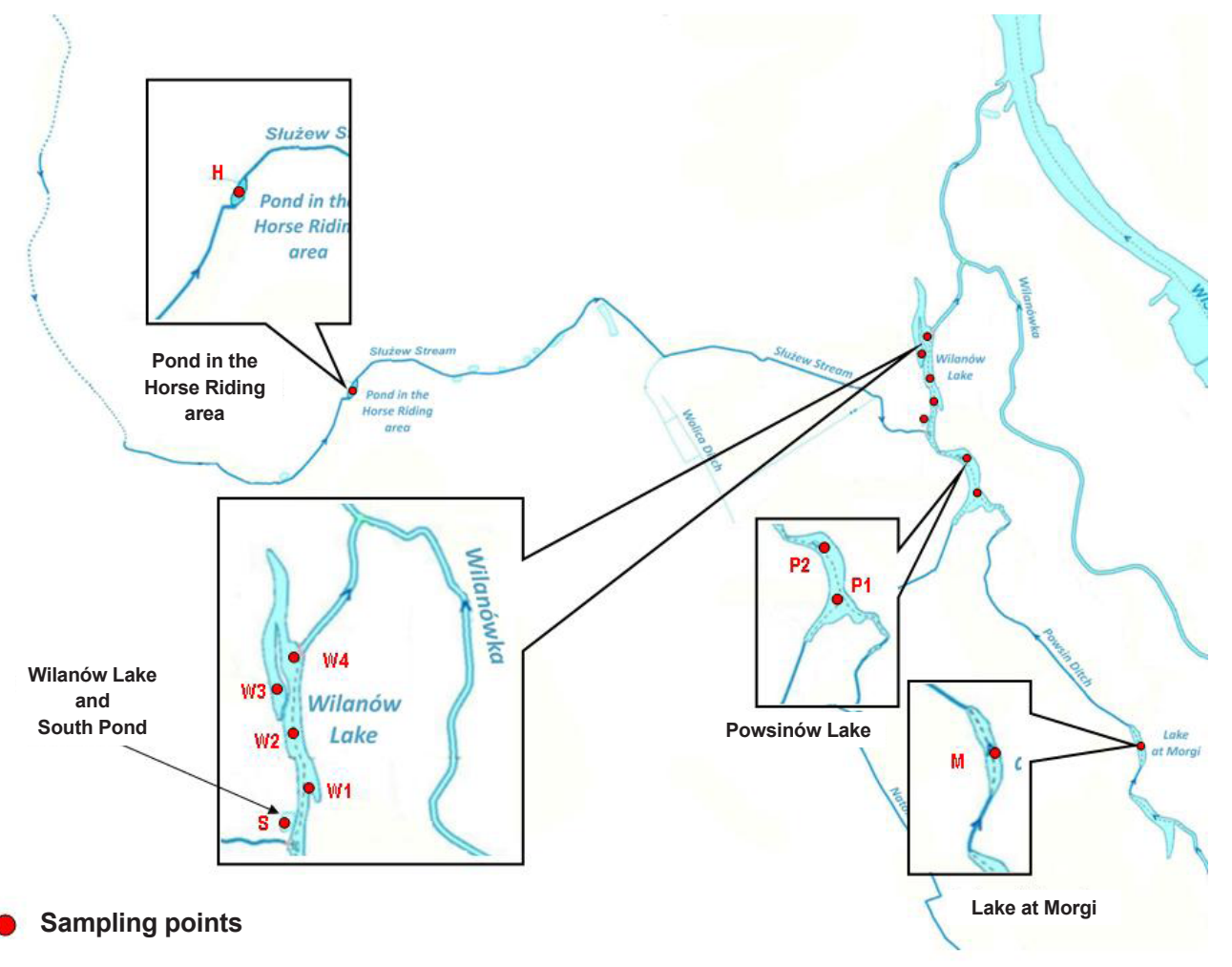

Fig. 1. Localization of sampling points 
sampler was used for collecting $20 \mathrm{~cm}$ top layers of sediments. Sampling was carried out jointly by the staff of the Municipal Chemical Laboratory, Office of the Capital City of Warsaw, and the Faculty of Environmental Engineering, Technical University of Warsaw.

Studies of water sediments were part of environmental monitoring research in the Służew Stream catchment. Initially, the study involved Wilanów Lake, Powsinów Lake and Lake at Morgi. Since 2008, the monitoring studies have been extended to Pond in the Horse Racing area and South Pond in Wilanów Park. Monitoring also included studies of Służewiec Stream sediment, the results of which are presented in a separate article (Bojakowska et al. 2012). The water sediments were analysed for the contents of chromium, copper, lead, zinc, nickel, cadmium and mercury. In the samples ground to a diameter of $<200$ microns, after aqua regia digestion, the $\mathrm{Cr}, \mathrm{Cu}, \mathrm{Pb}, \mathrm{Zn}, \mathrm{Ni}$ and $\mathrm{Cd}$ contents were determined by flame atomic absorption spectrometry, and the $\mathrm{Hg}$ content using atomic absorption spectrometry with amalgamation techniques. The determinations were performed by the Municipal Chemical Laboratory of the Office of the Capital City of Warsaw according to the Polish Standards or test procedures developed by the Laboratory.

\section{RESULTS AND DISCUSSION}

Water sediments of Wilanów Lake contain very high levels of heavy metals. The highest content was measured for zinc; its concentration ranged between 83 and $1430 \mathrm{mg} / \mathrm{kg}$, with the highest levels found at sampling points W1 and W2 (Fig. 2) located in the southern part of the reservoir, whereas at sampling point W3, its concentration was significantly lower, but still very high. The copper concentrations varied from 37 to $274 \mathrm{mg} / \mathrm{kg}$, and the highest geometric mean content was found in sediments collected from observation point W2, while the lowest value was measured at sampling point W3 (Fig. 3). The lead concentrations in the water sediments ranged between 18 and $200 \mathrm{mg} / \mathrm{kg}$, and, as in the case of copper, the highest concentration of this element was found at point W2, and the lowest one at W3 (Fig. 4). The concentration of cadmium varied from 1.4 to $10.0 \mathrm{mg} / \mathrm{kg}$, and the geometric mean values measured at observation points $\mathrm{W} 1$ and $\mathrm{W} 2$ are similar. The lowest geometric mean content was measured at point W3 (Fig. 2). The chromium concentration varied from 30 to $113 \mathrm{mg} / \mathrm{kg}$.
The highest levels were observed in the southern part of the reservoir, and the lowest contents were present in the sediments at observation point W3 (Fig. 3). The nickel concentration in the water sediments was relatively low $(28-50 \mathrm{mg} / \mathrm{kg}$ ) and its average values at all stations were similar, although a slightly elevated content was observed at survey point W2, and the lowest one at W3 (Fig. 4). The mercury concentration was in the range of 0.061 $0.810 \mathrm{mg} / \mathrm{kg}$. As in the case of other heavy metals, the highest average content was found in the sediments sampled at point W1, and the lowest concentration was measured at point W3 (Fig. 5). Water sediments of Powsinów Lake contained chromium in the range of $14-59 \mathrm{mg} / \mathrm{kg}$, and a slightly higher level was observed at sampling point $\mathrm{P} 2$. The copper concentration varied between 20 and $69 \mathrm{mg} / \mathrm{kg}$, and a significantly higher value was measured at point P2. The lead concentrations ranged from 25 to $68 \mathrm{mg} / \mathrm{kg}$, and, as in the case of other trace elements, a higher average value was found at point $P 2$. The zinc concentration varied in the range of $110-385 \mathrm{mg} / \mathrm{kg}$, and also in this case, higher values were measured at observation point $\mathrm{P} 2$. Nickel was present in the concentration range of $19-55 \mathrm{mg} / \mathrm{kg}$, and the geometric mean was the same for both sampling points. Cadmium is present in a narrow range of concentrations from 1.0 to $2.7 \mathrm{mg} / \mathrm{kg}$. Sediments from observation point $\mathrm{P} 2$ showed a slightly higher content of this element. The mercury concentration in the water sediments varied from 0.091 to $0.196 \mathrm{mg} / \mathrm{kg}$, and, as for most of the analysed elements, sediment samples taken from point $\mathrm{P} 2$ have a slightly higher $\mathrm{Hg}$ concentration. The chromium concentration in water sediments of Lake at Morgi ranged from 21 to $54 \mathrm{mg} / \mathrm{kg}$. The copper concentrations varied from 19 to $32 \mathrm{mg} / \mathrm{kg}$, and the lead concentration was in the range between 19 and $32 \mathrm{mg} / \mathrm{kg}$. The zinc concentration in the sediments varied between 113 and $261 \mathrm{mg} / \mathrm{kg}$, and the nickel concentration was $27-41 \mathrm{mg} / \mathrm{kg}$. Cadmium and mercury were present at very low concentrations $(<0.5-1.0 \mathrm{mg} / \mathrm{kg}$ and 0.066 $0.134 \mathrm{mg} / \mathrm{kg}$, respectively).

Water sediments of South Pond contained chromium in a very narrow range of $71-89 \mathrm{mg} / \mathrm{kg}$. Similarly, the copper concentrations also showed very low variability at a very high level (158$169 \mathrm{mg} / \mathrm{kg}$ ). Water sediments of South Pond contained very high levels of zinc (929-1100 mg/kg). The nickel concentration was relatively low ranging from 28 to $41 \mathrm{mg} / \mathrm{kg}$. The cadmium concentrations were higher by an order of magnitude than the geochemical
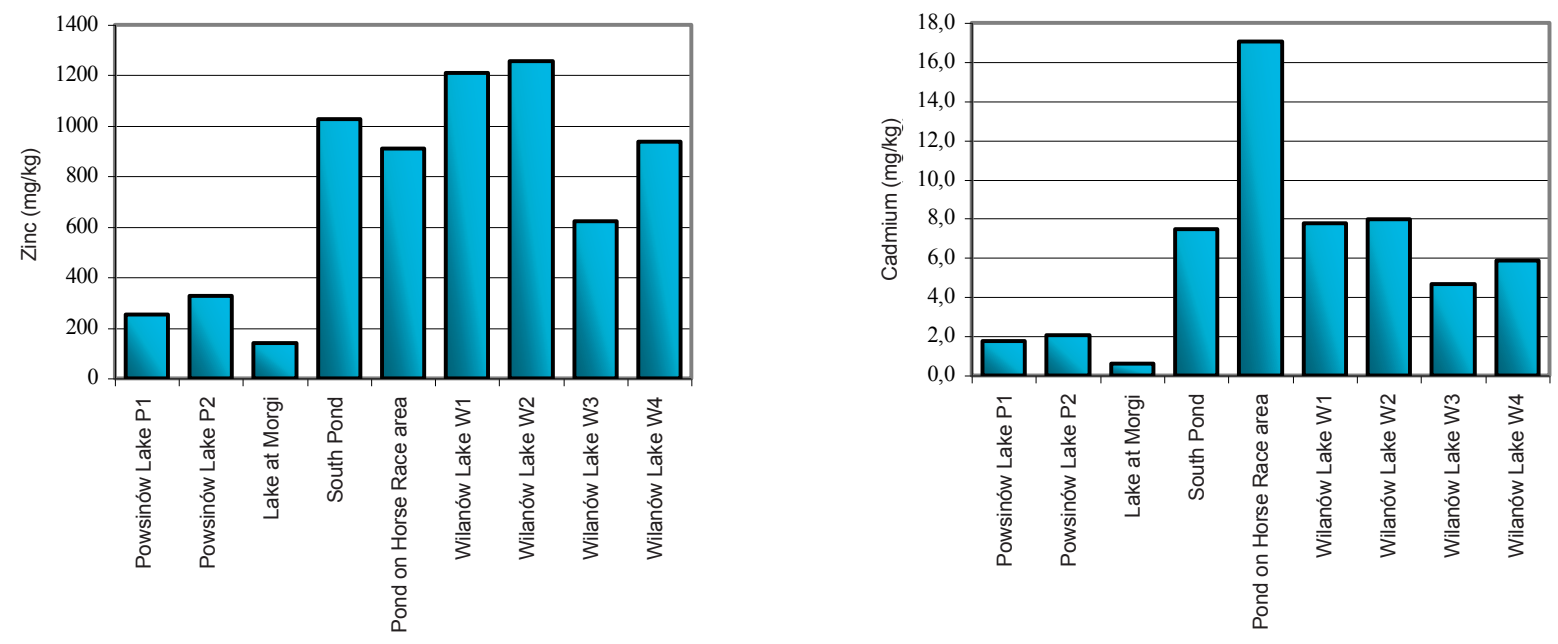

Fig. 2. Geometric mean concentrations of zinc and cadmium in the water sediments 

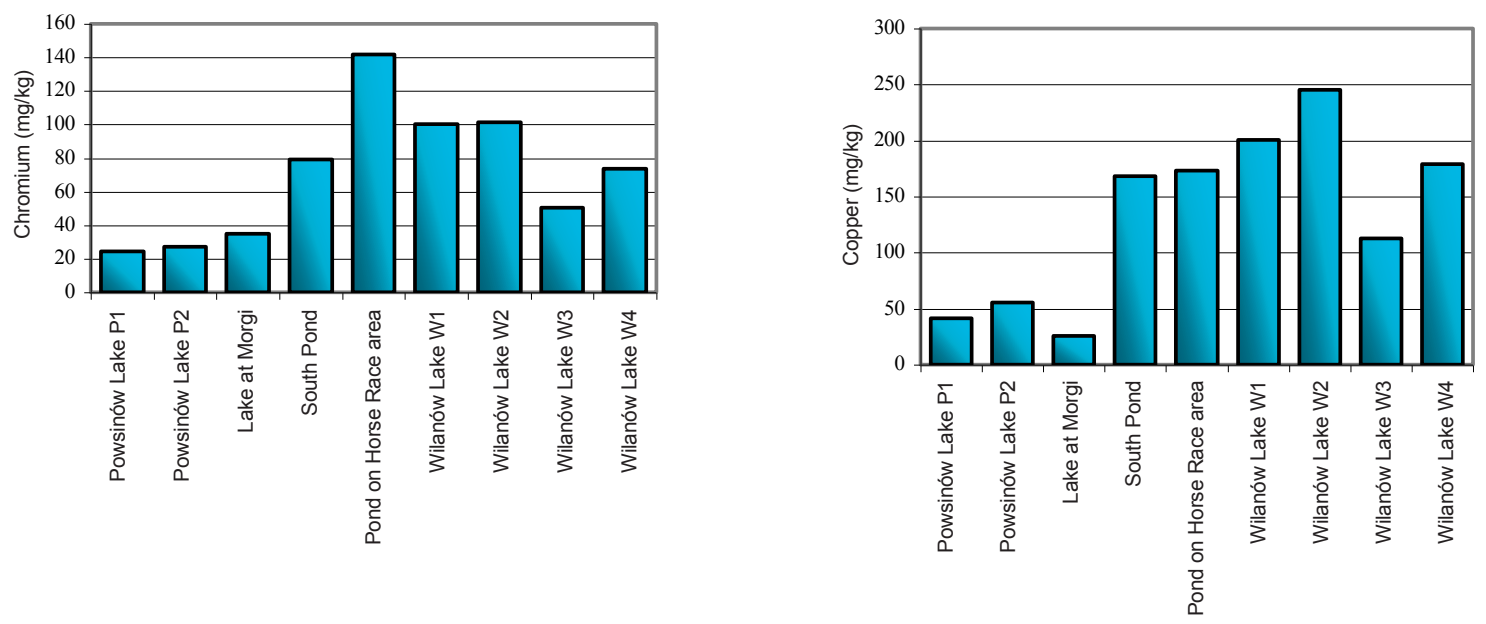

Fig. 3. Geometric mean concentrations of chromium and copper in the water sediments

background and varied from 6.5 to $8.2 \mathrm{mg} / \mathrm{kg}$. The mercury concentrations were elevated as compared with the value of the geochemical background, and varied from 0.270 to $0.506 \mathrm{mg} / \mathrm{kg}$.

Water sediments of Pond in the Horse Racing area show very high concentrations of heavy metals. The chromium concentration was in the range of $108-225 \mathrm{mg} / \mathrm{kg}$. The copper concentration was $101-206 \mathrm{mg} / \mathrm{kg}$, and the lead was present at concentrations of $106-310 \mathrm{mg} / \mathrm{kg}$. The highest concentrations, $508-1110 \mathrm{mg} / \mathrm{kg}$, were observed for zinc. Nickel was found at relatively low concentration $(27-47 \mathrm{mg} / \mathrm{kg})$. The water sediments contained very high concentrations of cadmium, which varied from 11.6 to $37.3 \mathrm{mg} / \mathrm{kg}$. The mercury concentrations were in the range of $0.267-0.560 \mathrm{mg} / \mathrm{kg}$.

The content of trace elements, including heavy metals, in the water sediments is mainly controlled by the geology of the drainage basin and the way of its development and land use. Pleistocene and Holocene deposits that occur in the area of Warsaw, tills, clays, sands, silts, peats and gyttjas, are characterised by low contents of potentially harmful metals and therefore their natural content in water sediments of watercourses, lakes and ponds - resulting from sedimentation of allochthonous material derived from erosion of these rocks and soils in the catchment area - should be very low and not exceed $0.05 \mathrm{mg} / \mathrm{kg}$ of mercury, $0.5 \mathrm{mg} / \mathrm{kg}$ of cadmium, a few $\mathrm{mg} / \mathrm{kg}$ of cobalt, chromium, copper and nickel, and several tens of $\mathrm{mg} / \mathrm{kg}$ of zinc (Lis, Pasieczna 1995).

Erratic stones, observed in the glacial tills, fragments of rocks and boulders (various types of porphyry, granites, basalts, sandstones, quartzites and limestones) can be a source of trace elements. The examined sediments contained 5-274 $\mathrm{mg} / \mathrm{kg}$ of chromium, and the geometric means calculated for all observation points ranged from $23 \mathrm{mg} / \mathrm{kg}$ (Powsinów Lake) to $136 \mathrm{mg} / \mathrm{kg}$ (Pond in the Horse Racing area) and were significantly higher than the background value for surface water sediments in Poland, which is $6 \mathrm{mg} / \mathrm{kg}$ (Lis, Pasieczna 1995). As regards the chromium content according to the geochemical classification (Bojakowska, Sokołowska 1998), water sediments of Powsinów Lake and Lake at Morgi are unpolluted $(\mathrm{Cr}$ concentrations are below $50 \mathrm{mg} / \mathrm{kg})$, sediments of South Pond and Wilanów Lake are moderately contaminated $(\mathrm{Cr}$ concentrations are in the range of $50-100 \mathrm{mg} / \mathrm{kg}$ ), and the only contaminated water sediments are those from Pond in the Horse Racing area ( $\mathrm{Cr}$ concentration varies from 100 to $400 \mathrm{mg} / \mathrm{kg}$ ). The copper concentration was in the range of $5-274 \mathrm{mg} / \mathrm{kg}$, and the geometric mean value varied between $26 \mathrm{mg} / \mathrm{kg}$ (Lake at Morgi) and $244 \mathrm{mg} / \mathrm{kg}$ (Wilanów Lake). The values, as in the case of
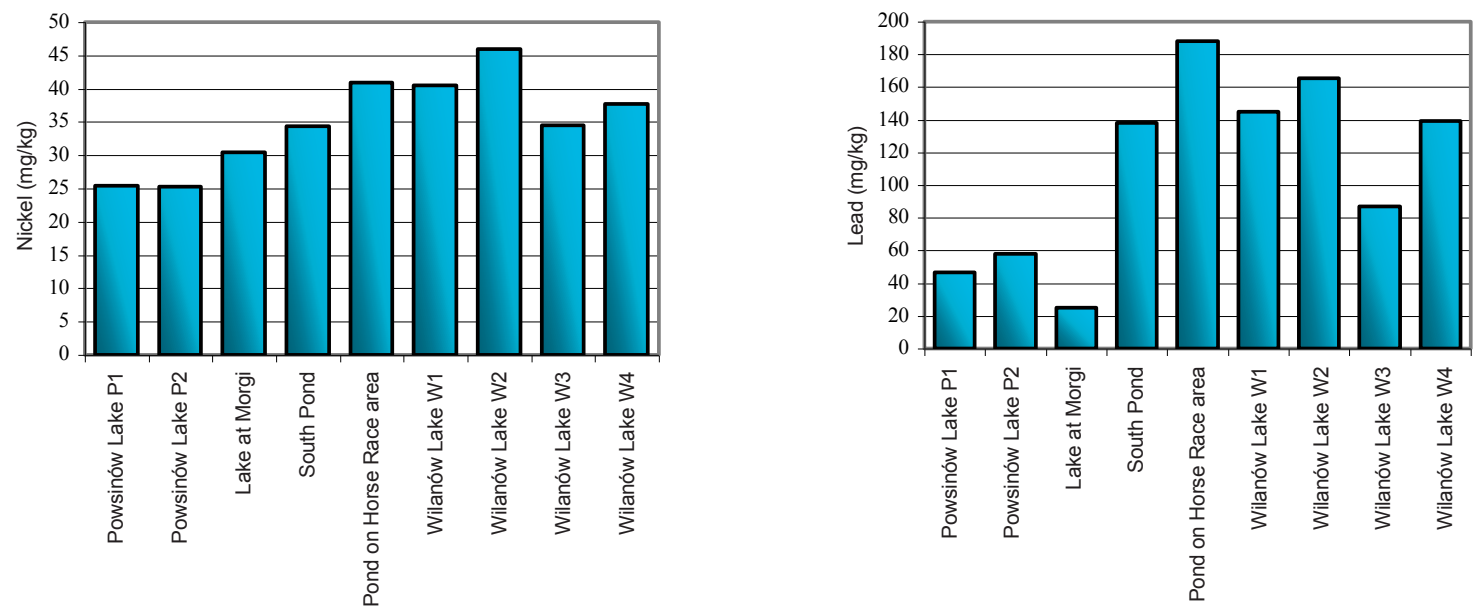

Fig. 4. Geometric mean concentrations of nickel and lead in the water sediments 


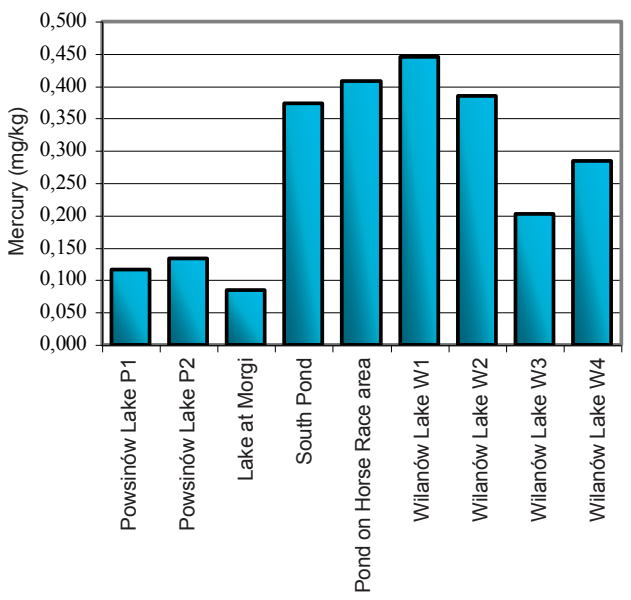

Fig. 5. Geometric mean concentrations of mercury in the water sediments

chromium, were many times higher than the background concentration of this element in water sediments of Poland $(7 \mathrm{mg} / \mathrm{kg})$. As regards the copper content, only water sediments of Lake at Morgi are considered unpolluted ( $\mathrm{Cu}$ concentration is below $40 \mathrm{mg} / \mathrm{kg}$ ), while water sediments from the other lakes are contaminated $(\mathrm{Cu}$ concentration is in the range of $100-300 \mathrm{mg} / \mathrm{kg}$ ).

The lead concentration in the water sediments varied from 3 to $310 \mathrm{mg} / \mathrm{kg}$, and the geometric means ranged from $25 \mathrm{mg} / \mathrm{kg}$ (Lake at Morgi) to $181 \mathrm{mg} / \mathrm{kg}$ (Pond in the Horse Racing area). For comparison, the background lead concentration in water sediments of Poland is $11 \mathrm{mg} / \mathrm{kg}$ (Lis, Pasieczna 1995). As regards the lead content according to the geochemical classification, only water sediments of Lake at Morgi are unpolluted $(\mathrm{Pb}$ concentration is below $30 \mathrm{mg} / \mathrm{kg}$ ), while water sediments of Powsinów Lake are moderately polluted $(\mathrm{Pb}$ concentration is in the range of 30 $100 \mathrm{mg} / \mathrm{kg}$ ). Sediments of the other water bodies are contaminated with this element ( $\mathrm{Pb}$ concentration is $100-200 \mathrm{mg} / \mathrm{kg}$ ). Zinc was present in the water sediments at the concentrations ranging from 44 to $1430 \mathrm{mg} / \mathrm{kg}$, and the calculated geometric means varied from $137 \mathrm{mg} / \mathrm{kg}$ (Lake at Morgi) to $1252 \mathrm{mg} / \mathrm{kg}$ (Wilanów Lake) and were higher than the geochemical background of $\mathrm{Zn}$ in water sediments of Poland, i.e. 73 mg/kg (Lis, Pasieczna 1995). As regards the zinc concentration in the water sediments, only those from Lake at Morgi are unpolluted ( $\mathrm{Zn}$ concentration is less than $200 \mathrm{mg} / \mathrm{kg}$ ). Water sediments of Lake Powsinkowskie are moderately polluted ( $\mathrm{Zn}$ concentration is in the range of 200-500 mg/kg), and the Wilanów Lake sediments at observation points $\mathrm{W} 1$ and $\mathrm{W} 2$ are highly contaminated (Zn concentrations are $>1000 \mathrm{mg} / \mathrm{kg}$ ). The nickel concentrations in the water sediments varied in the range of 3-55 mg/kg, and the geometric mean values ranged from $25 \mathrm{mg} / \mathrm{kg}$ (Powsinów Lake) to $46 \mathrm{mg} / \mathrm{kg}$ (Wilanów Lake). The geochemical background value in Poland is $7 \mathrm{mg} / \mathrm{kg}$. As regards the nickel content, the water sediments can be considered as moderately polluted ( $\mathrm{Ni}$ concentration is $16-$ $40 \mathrm{mg} / \mathrm{kg}$ ) except for observation point W2 in Wilanów Lake. The cadmium concentrations were in the range of $<0.5-37.3 \mathrm{mg} / \mathrm{kg}$, and the geometric mean values ranged from $0.6 \mathrm{mg} / \mathrm{kg}$ (Lake Pod Morgami) to $15.6 \mathrm{mg} / \mathrm{kg}$ (Pond in the Horse Racing area). The cadmium geochemical background in water sediments of Poland is $<0.5 \mathrm{mg} / \mathrm{kg}$. Considering the presence of cadmium in the water sediments, only those from Lake at Morgi can be assessed as uncontaminated ( $\mathrm{Cd}$ concentrations are below $1.0 \mathrm{mg} / \mathrm{kg}$ ), the Powsinów Lake sediments are regarded as moderately polluted (Cd concentration is in the range of $1-3.5 \mathrm{mg} / \mathrm{kg}$ ), and the South Pond,
Pond in the Horse Racing area and Wilanów Lake sediments (at observation points W1 and W2) as highly contaminated ( $\mathrm{Zn}$ concentrations are above $6 \mathrm{mg} / \mathrm{kg}$ ). The mercury concentrations in the examined samples varied from 0.010 to $0.810 \mathrm{mg} / \mathrm{kg}$, and the geometric means ranged from $0.084 \mathrm{mg} / \mathrm{kg}$ (Lake at Morgi) to $0.432 \mathrm{mg} / \mathrm{kg}$ (Wilanów Lake). For comparison, the geometric mean of mercury concentration in water sediments of Poland is $<0.05 \mathrm{mg} / \mathrm{kg}$. As regards mercury, the sediments are considered unpolluted (Powsinów Lake, Lake at Morgi, Hg concentrations are below $0.2 \mathrm{mg} / \mathrm{kg}$ ) or moderately polluted (South Pond, Pond in the Horse Racing area, Wilanów Lake, Hg concentrations range from 0.2 to $0.5 \mathrm{mg} / \mathrm{kg}$ ).

In terms of ecotoxicological criteria, the calculated geometric mean levels of some elements are higher than the probable effect concentration (PEC) values evaluated for the sediments, above which harmful effects are frequently observed in organisms inhabiting the water (MacDonald et al. 2000). Only the nickel and mercury concentrations, even though significantly elevated, are lower than the PEC in all the water bodies. Higher than the PEC value is the chromium concentration (111 $\mathrm{mg} / \mathrm{kg}$ ) determined in water sediments of Pond in the Horse Racing area; the copper concentration $(149 \mathrm{mg} / \mathrm{kg})$ in water sediments of South Pond, Pond in the Horse Racing area and southern Wilanów Lake; the lead concentration $(128 \mathrm{mg} / \mathrm{kg})$ and the cadmium concentration $(4.98 \mathrm{mg} / \mathrm{kg})$ in water sediments of South Pond, Pond in Pond in the Horse Racing area and Wilanów Lake (points C1, C2 and C4); and the zinc concentration $(459 \mathrm{mg} / \mathrm{kg})$ in water sediments of southern part of Wilanów Lake and South Pond.

The maximum concentrations of chromium, copper and zinc reported in the sediments of Wilanów Lake, South Pond and Pond in the Horse Racing area were much higher than the maximum levels of these elements in sediments of lakes in Seoul, Korea, which contained up to $104 \mathrm{mg} / \mathrm{kg}$ of chromium, up to $112 \mathrm{mg} / \mathrm{kg}$ of copper and more than $400 \mathrm{mg} / \mathrm{kg}$ of zinc, but the sediments from Warsaw reservoirs contain significantly less cadmium compared with the sediments from Seoul, in which up to $63 \mathrm{mg} / \mathrm{kg}$ of Cd was detected (Baek, An 2010). The average content of cadmium, chromium, copper and lead in the sediments of Wilanów Lake, South Pond and Pond in the Horse Racing area was comparable with their concentrations in the sediments of lakes in Bangalore, India; however, the average concentration of zinc in the sediments of lakes and ponds from Warsaw was several times higher (Jumbe, Nandini 2009). The reported content of $\mathrm{Cd}, \mathrm{Cr}, \mathrm{Cu}, \mathrm{Hg}, \mathrm{Ni}, \mathrm{Pb}$ and $\mathrm{Zn}$ in the sediments of Powsinów Lake and Lake at Morgi was 
comparable with the levels of these metals in sediments of urban lakes in Switzerland (Wildi et al. 2004).

The source of heavy metals that accumulated in the reservoirs supplied by the Służew Stream waters is wastewater discharged into the stream in the past, especially from the Służewiec industrial area. Currently, elevated concentrations of heavy metals are still observed in water sediments of the Służew Stream in comparison with the values of their geochemical background. The highest content of heavy metals $-\mathrm{Cr}, \mathrm{Ni}, \mathrm{Hg}, \mathrm{Cu}, \mathrm{Zn}$ and $\mathrm{Pb}$ - were detected in the sediments collected from the Służew Stream near the airport. Increased contents of $\mathrm{Cr}, \mathrm{Cu}, \mathrm{Zn}, \mathrm{Pb}$ and $\mathrm{Hg}$ are also observed downstream of the confluence with the Wolica Canal. In the case of cadmium, increased contents were found in sediments accumulated in the grounds of the former Służewiec industrial area (Bojakowska et al. 2012).

The heavy metal contents observed in the Służew Stream sediments (geometric mean contents were as follows: for $\mathrm{Cr}-21 \mathrm{mg} / \mathrm{kg}$, $\mathrm{Cu}-19 \mathrm{mg} / \mathrm{kg}, \mathrm{Pb}-19 \mathrm{mg} / \mathrm{kg}, \mathrm{Ni}-7 \mathrm{mg} / \mathrm{kg}, \mathrm{Cd}-1.9 \mathrm{mg} / \mathrm{kg}, \mathrm{Zn}-$ $126 \mathrm{mg} / \mathrm{kg}$ and $\mathrm{Hg}-0.040 \mathrm{mg} / \mathrm{kg}$ ) were significantly lower than those calculated for lakes and ponds supplied by the stream. In a longer term, sedimentation of the material transported by the Służew Stream will reduce the concentration of heavy metals in the sediments of reservoirs supplied by the stream.

\section{REFERENCES}

ADACHI K, TAINOSHO Y. 2004.Characterization of heavy metal particles embedded in tire dust. Environ Int.30: 1009-1017.

BAEK Y-W., AN Y-J. 2010 - Assessment of toxic heavy metals in urban lake sediments as related to urban stressor and bioavailability. Environ. Monit. Assess. 171: 529-537. DOI 10.1007/ s10661-009-1297-7.

BAKER, L. 2009. New concepts for urban pollution. In: Baker, L. (ed), The Water Environment of Cities, Springer Science, Lowell, MA. DOI 10.1007/978-0-387-84891-4 5.

BIERNACKI Z. 2000. Geomorfologia i wody powierzchniowe. w: Wisła w Warszawie. Biuro Zarządu m.st. Warszawa. Wydział Planowania Przestrzennego i Architektury.

BOJAKOWSKA I. SOKOŁOWSKA G. 1998. Geochemiczne klasy czystości osadów wodnych. Przegląd Geologiczny, 46 (1) 49-54.

BOJAKOWSKA J., DUSZYŃSKI J., JAROŃ J., KARMARZ D. KUCHARZYK J., MAKSYMOWICZ A. 2009. Pierwiastki śladowe w pyłach tuneli drogowych na terenie Warszawy. Przegląd Geologiczny, 57: 1069-1072.

BOJAKOWSKA I., LECH D., JAROSZYŃSKA J. 2012 - Metale ciężkie w osadach Potoku Służewieckiego w Warszawie (Polska). Górnictwo i Geologia. 7(2): 71-83.

CHRISTOFORDIS A., STAMATIS N. 2009. Heavy metals concentrations in street dust and roadside soil along the major national road in Kavala's region, Greece. Geoderma 151 (2009): 257-263.

FERREIRA-BAPTISTA L, MIGIEL E. 2005. Geochemistry and risk assessment of street dust in Luanda, Angola: A tropical urban environment. Atmospheric Environment 39 (2005): 4501-4512.

GUNEY M., ONAYA T., COPTY N. 2009. Impact of overland traffic on heavy metal levels in highway dust and soils of Istanbul, Turkey. Environmental Monitoring and Assessment. DOI 10.107/ s10661-009-0878.

JUMBE A., NANDINI N. 2009. Heavy Metals Analysis and Sediment Quality Values in Urban Lakes. American Journal of Environmental Sciences 5 (6): 678-687.

\section{CONCLUSIONS}

Studies have shown that water sediments of Pond in the Horse Racing area, South Pond and Wilanów Lake, supplied by the waters of the Służew Stream, to which industrial wastewater was discharged for many years, show a very high content of heavy metals. Water sediments of Powsinów Lake and Lake at Morgi, fed by the waters of drainage ditches flowing into the Służew Stream, are characterized by much lower concentrations of these elements but the values are much higher than the geochemical background of $\mathrm{Cr}, \mathrm{Cu}, \mathrm{Pb}, \mathrm{Zn}, \mathrm{Ni}, \mathrm{Cd}$ and $\mathrm{Hg}$.

In terms of geochemical criteria, water sediments of Lake at Morgi and Powsinów Lake can be assessed as moderately polluted due to the presence of nickel, copper, lead, chromium and zinc. Sediments of the other reservoirs are characterized by very high concentrations of these elements, several to ten times higher than the geochemical background values. Water sediments of South Pond are heavily polluted by zinc and cadmium. Sediments of Pond in the Horse Racing area are contaminated by zinc, copper, chromium, lead and nickel, and those of Wilanów Lake, accumulated in the southern part of the lake (sampling points W1 and W2), are highly contaminated by cadmium and zinc. In the northern part (points W3 and $\mathrm{W} 4)$, they are contaminated by $\mathrm{Zn}, \mathrm{Cd}, \mathrm{Cu}, \mathrm{Cr}$ and $\mathrm{Pb}$.

KABATA-PENDIAS A., MUKHERJEE A. 2007.- Trace elements from soil to human. Springer. Berlin, Heidelberg, New York. pp. 550.

LANDRE A., WINTER J., HELM P., HIRIART-BAER V., YOUNG J. 2011. Metals in Lake Simcoe sediments and tributaries: Do recent trends indicate changing sources? Journal of Great Lakes Research 37 (Suplement): 124-131.

LEGRET M., PAGOTTO C. 2006. Heavy metal deposition and soil pollution along two major rural highways. Environmental Technology 27: 247-254.

LINDSTRÖM M. 2001. Urban land use influences on heavy metal fluxes and surface sediment concentrations of small lakes. Water, Air \& Soil Pollution, Vol: 126: 363-383. DOI: 10.1023/a:1005291611702.

LIS J., PASIECZNAA. 1995. Atlas geochemiczny Polski w skali 1:2 500 000. Wyd. Geologiczne. Warszawa.

MACDONALD D., INGERSOLL C., BERGER T. 2000. Development and Evaluation of consensus-based Sediment Development and evaluation of consensus-based sediment quality guidelines for freshwater ecosystems. Archives of Environmental Contamination and Toxicology 39: 20-31.

MCKENZIE E., MONEY J., GREEN P. YOUNG T. 2009. Metals associated with stormwater-relevant brake and tire samples. Sci Total Environ. 2009 November 1; 407(22): 5855-5860.

NAGEOTTE S., DAY J. 1998 - Lead concentrations and isotope rations in street dust determined by electrothermal; atomic absorption spectrometry and inductively coupled plasma mass spectrometry. Analsyt. Journal 123: 59-62.

OKORO I., ORIAKU C., EJIKE E. 2007. Lead Characterization of street dust in some cities of south eastern Nigeria. Research Journal of Applied Sciences 2 (1): 39-42.

ORDÓÑEZA., LOREDO J., De MIGUEL E., CHARLESWORTH S. 2003. Distribution of heavy metals in the street dusts and soils of an industrial city in Northern Spain. Archives of Environmental Contamination Toxicology 44: 160-170.

POLKOWSKA, Z.; NAMIEŚNIK, J. 2008. Road and roof runoff waters as a source of pollution in a big urban agglomeration 
(Gdansk, Poland). Ecological Chemistry and Engineering S 2008, 15 (3): 375-385.

QUEK U., FORSTER J. 1993. Trace metals in roof runoff. Water, Air, and Soil Pollution, 68: 373-389.

SEKABIRA K., ORIGA H., BASAMBA T., MUTUMBA G., KAKUDIDI E. 2010. Assessment of heavy metal pollution in the urban stream sediments and its tributaries. Int. J. Environ. Sci. Tech., 7 (3): 435-446.

SEZGIN N., OZCAN H.K., DEMIR G., NEMLIOGLU S., BAYAT C. 2003. Determination of heavy metal concentrations in street dusts in Istanbul E-5 highway. Environment International 29: 979-985.

SHINGGU D., OGUGBUAJA V., BARMINAS J., TOMA I. 2007

- Analysis of street dust for heavy metals pollutants in Mubi,
Adamawa State, Nigeria. International Juotnal of Physical Studiies 2(11): 290-293.

VINK J. 2009. The origin of speciation: Trace metal kinetics over natural water/sediment interfaces and the consequences for bioaccumulation. Environmental Pollution 157: 519-527.

WILDI W., DOMINIK J., LOIZEAU J., THOMAS R. FAVARGER P. HALLER L., PERROUD A., PEYTREMANN C. 2004 - River, reservoir and lake sediment contamination by heavy metals downstream from urban areas of Switzerland. Lake Reserv. Res. Manage. 9 (1): 75-87.

ZHAO H., YIN C., CHEN M., WANG W. 2009. Risk assessment of heavy metals in street dust particles to a stream network. Soil and Sediment contamination: An International Journal. 18 (2): 173-183. 